https://doi.org/10.18778/1509-877X.2019.04.04

Artykuły

Aleksandra Krajewska*

\title{
KILKA UWAG NA TEMAT OPODATKOWANIA WYDOBYCIA KOPALIN W WYBRANYCH KRAJACH
}

\begin{abstract}
Streszczenie. W artykule dokonano zwięzłego przeglądu podatków wydobywczych występujących w systemach fiskalnych wybranych państw świata. W pierwszej kolejności wskazano definicję pojęcia „renty surowcowej” oraz przedstawiono systemy nadające kształt współpracy pomiędzy państwami władającymi złożami kopalin oraz przedsiębiorcami dokonującymi ich wydobycia (tj. system koncesyjny i kontraktowy). W dalszej kolejności dokonano krótkiej charakterystyki danin obciążających działalność wydobywczą na świecie, dokonując ich klasyfikacji z uwzględnieniem różnych kryteriów. Następnie zaś przedstawiono instrumenty fiskalne stosowane w sektorze wydobywczym w Australii, Norwegii, Kanadzie i Meksyku (głównie w odniesieniu do węglowodorów, tj. ropy naftowej i gazu ziemnego).
\end{abstract}

Słowa kluczowe: opodatkowanie wydobycia kopalin, opodatkowanie sektora wydobywczego, podatki wydobywcze, renta surowcowa

\section{WPROWADZENIE}

W niniejszym artykule przedstawiono narzędzia fiskalne służące opodatkowaniu wydobycia kopalin w wybranych krajach świata. Rozważania rozpoczęto od krótkiej charakterystyki systemów nadających kształt współpracy pomiędzy państwem gospodarującym złożami a przedsiębiorcami dokonującymi wydobycia kopalin, przeglądu danin obciążających działalność wydobywczą oraz wyjaśnienia istotnego w tym kontekście

* Doktor nauk prawnych, Katedra Prawa Podatkowego, Wydział Prawa i Administracji, Uniwersytet Łódzki, radca prawny, współpracownik Centrum Dokumentacji i Studiów Podatkowych oraz Fundacji CDiSP, e-mail: akrajewska@wpia.uni.lodz.pl 
pojęcia „renty surowcowej”. Następnie uwagę skupiono na rozwiązaniach przyjętych w tym zakresie w Australii, Norwegii, Kanadzie i Meksyku, głównie w odniesieniu do węglowodorów (ropy naftowej i gazu ziemnego) ze względu na strategiczne znaczenie wskazanych kopalin w światowym górnictwie. Doboru krajów dokonano ze względu na szeroki wachlarz stosowanych w nich instrumentów fiskalnych w sektorze wydobywczym, a także rozmieszczenie geograficzne i chęć poddania analizie krajów zlokalizowanych na różnych kontynentach.

Podkreślenia wymaga przekrojowy, syntetyczny charakter niniejszego opracowania - jego celem jest bowiem dokonanie zwięzłego przeglądu mechanizmów fiskalnych funkcjonujących w branży wydobywczej we wskazanych wyżej państwach z uwzględnieniem wybranych ich aspektów.

\section{INSTRUMENTY FISKALNE W SEKTORZE WYDOBYWCZYM}

W piśmiennictwie podkreśla się wysoki stopień zróżnicowania rozwiązań fiskalnych stosowanych na świecie w odniesieniu do sektora wydobywczego $^{1}$. „Różnorodność ta odnosi się nie tylko do rodzaju, formy czy ilości wykorzystywanych instrumentów, ale przede wszystkim odzwierciedla politykę państwa w zakresie własności i kontroli surowców naturalnych oraz regulacji sektora wydobywczego. Nie bez znaczenia w tym względzie pozostają uwarunkowania historyczne, ustrój polityczny i gospodarczy, a także poziom rozwoju gospodarczego i zdolność aparatu skarbowego do wdrożenia i stosowania określonych rozwiązań fiskalnych"2. Na kształt rozwiązań podatkowych przyjętych w poszczególnych krajach w obszarze górnictwa silnie oddziałuje zatem wiele czynników pozaprawnych. W mojej ocenie do najważniejszych zaliczyć należy naturalny potencjał geologiczny danego państwa przejawiający się w poziomie jego zasobności w złoża określonych kopalin, aktualne zdolności technologiczne wpływające na możliwość eksploatacji tych złóż oraz szeroko rozumiany kontekst polityczny i budżetowy związany $\mathrm{z}$ ogólnymi założeniami przyjętej $\mathrm{w}$ danym kraju polityki surowcowej oraz znaczeniem danin sektorowych w strukturze budżetu.

Przed omówieniem najpowszechniejszych danin uiszczanych globalnie przez podmioty prowadzące działalność wydobywczą przywołać

1 A. Świstak, Opodatkowanie wydobycia surowców naturalnych w Polsce, Warszawa 2018, s. 51 .

2 Ibidem. 
należy istotną koncepcję renty surowcowej. W literaturze światowej pojęcie to definiowane jest w sposób szeroki jako nadwyżka przychodów ze sprzedaży surowca nad całkowitymi kosztami jego wydobycia ${ }^{3}$. Z punktu widzenia interesów państw gospodarujących złożami kopalin renta surowcowa może być z kolei postrzegana ,jako całokształt kwot należnych państwu w zamian za korzystanie z należących do niego złóż polegające na wydobyciu i sprzedaży surowców" ". Renta surowcowa stanowi więc rodzaj wynagrodzenia uiszczanego na rzecz państwa będącego właścicielem surowców w zamian za udzieloną przedsiębiorcy zgodę na ich wydobycie (powodujące najczęściej ubożenie bądź przynajmniej wyczerpywanie tych dóbr naturalnych $)^{5}$. W poszczególnych państwach w skład renty surowcowej wchodzą rozmaite daniny charakteryzujące się różną konstrukcją, zakresem (przedmiotowym i podmiotowym) oraz wysokością.

Przyjęcie odrębnych zasad opodatkowania eksploatacji złóż zasobów naturalnych, uwzględniających specyfikę tej dziedziny gospodarki oraz szczególny przedmiot opodatkowania, można uznać za powszechną praktykę globalną ${ }^{6}$ Cechą charakterystyczną światowego górnictwa jest obciążanie go nie tylko podatkami „standardowymi”, ale również daninami odrębnymi, specjalnymi, pobieranymi w ścisłym związku z przedmiotem działalności ${ }^{7}$. Nie przyjęto jednak w tym zakresie globalnie jednolitego podejścia i poszczególne kraje stosują różnorodne formy opodatkowania kopalin ${ }^{8}$, których kombinacje tworzą charakterystyczne dla tych państw systemy wynikające z sygnalizowanych na wstępie artykułu uwarunkowań.

${ }^{3}$ Por. B.C. Land, Resource rent taxes: A re-appraisal, [w:] The Taxation of Petroleum and Minerals: Principles, Problems and Practice, red. P. Daniel, M. Keen, C. McPherson, International Monetary Fund 2010.

${ }^{4}$ A. Krajewska, Podatki wydobywcze - ocena systemu opodatkowania wydobycia niektórych kopalin w Polsce na tle rozwiązań wybranych krajów, rozprawa doktorska obroniona na Wydziale Prawa i Administracji Uniwersytetu Łódzkiego w 2019 r., s. 30.

${ }^{5}$ Uzasadnienie projektu z dnia 19 stycznia 2012 r. ustawy o podatku od wydobycia niektórych kopalin, druk sejmowy nr 144/VII kadencja, s. 6, http://orka.sejm.gov.pl/ Druki7ka.nsf/0/4CF0BD2A47EA2687C125798E003F4D1A/\%24File/144.pdf (dostęp: 3.09.2020), dalej: projekt u.p.w.n.k.

${ }^{6}$ M. Grabicz, H. Sokół, Pułapki opodatkowania gazu łupkowego w Polsce, „Rynek Energii" 2012, nr 3, s. 1.

7 J. Kulczycka, M. Nieć, R. Uberman, Określenie ilości wydobytej kopaliny stałej przy naliczaniu opłaty eksploatacyjnej. Pojęcia i zasady, Kraków 2003, s. 15.

8 M. Grabicz, H. Sokół, Pułapki opodatkowania..., s. 1. 
Analizując kształt współpracy oraz podział zysków płynących z eksploatacji złóż bogactw naturalnych pomiędzy państwem będącym gospodarzem tych złóż a przedsiębiorcami prowadzącymi działalność wydobywczą, należy wskazać dwa systemy: koncesyjny i kontraktowy. W systemach koncesyjnych „prawo do zasobów przechodzi na inwestora na określony czas, a państwo czerpie dochody z podatków [...] i opłat"9. Z kolei podstawą systemów kontraktowych są umowy zawierane pomiędzy państwem a przedsiębiorcą, które mogą przybrać formę zarówno kontraktów usługowych, jak i kontraktów na wspólną produkcję. Państwu przysługuje wówczas prawo do zasobów (oraz zysków płynących $\mathrm{z}$ tego tytułu w różnych formach), podczas gdy przedsiębiorca zachowuje co najwyżej prawo do części produkcji bądź osiąganych z niej zysków ${ }^{10}$. Należy podkreślić, że rozwiązania stosowane zarówno w przypadku relacji koncesyjnej, jak i kontraktowej „w żadnym razie nie przenoszą na inwestora własności surowców mineralnych, jedynie nadają kształt tymczasowej relacji związanej z przeprowadzeniem inwestycji wydobywczej"11.

W skład renty surowcowej wchodzą różnorodne obciążenia nakładane na podmioty wydobywcze, mające zarówno charakter podatków, jak i opłat. Daniny te mogą podlegać rozmaitym klasyfikacjom. Przykładowo, biorąc pod uwagę konstrukcję obciążeń, wyróżnić można daniny od wielkości wydobycia, daniny od zysku z działalności wydobywczej oraz podatki rentowe $^{12}$. Pierwsze $\mathrm{z}$ nich stanowią pojemną kategorię danin określanych w światowej literaturze mianem royalties, których cechą charakterystyczną jest powiązanie ich wysokości m.in. z ilością wydobytej kopaliny bądź wielkością eksploatowanego obszaru ${ }^{13}$. Z punktu widzenia interesów państwa władającego złożami kopalin opłaty te są niewątpliwie korzystne, biorąc pod uwagę łatwość ich poboru oraz brak uzależnienia ich wysokości od rzeczywistej rentowności przedsięwzięć wydobywczych (co stanowi z kolei wadę z perspektywy prowadzących wydobycie przedsiębiorców). Druga kategoria obejmuje daniny, których wysokość uzależniona jest od zysków

${ }^{9}$ J. Neneman, J. Kronenberg, Opodatkowanie eksploatacji złóż gazu łupkowego $w$ Polsce i jego wpływ na gospodarke w świetle koncepcji „przekleństwa zasobów naturalnych”, „Acta Universitatis Lodziensis. Folia Oeconomica” 2014, nr 5, s. 44.

${ }^{10}$ Ibidem.

11 A. Krajewska, Podatki wydobywcze..., s. 18; por. S. Tordo, Fiscal Systems for Hydrocarbons, World Bank Working Paper No. 123, Washington 2007, s. 4.

12 Uzasadnienie projektu u.p.w.n.k., s. 7.

13 J. Kulczycka, M. Nieć, R. Uberman, Określenie ilości..., s. 15. 
osiągniętych z działalności wydobywczej. Szczególnym ich rodzajem są specjalne podatki surowcowe, które stanowią w istocie rodzaj elastycznego podatku dochodowego nakładanego na podmioty funkcjonujące w branży wydobywczej (o znacznie zredukowanym zakresie przedmiotowym i podmiotowym w stosunku do „klasycznego" podatku dochodowego. Biorąc pod uwagę relację pomiędzy wysokością uiszczanej daniny a realnymi wpływami z działalności wydobywczej, daniny tego typu są znacznie korzystniejsze dla przedsiębiorców i zasługują na lepszą ocenę w kontekście koncepcji sprawiedliwości opodatkowania ${ }^{14}$. W przypadku podatków rentowych opodatkowaniu podlegają zaś przepływy netto kalkulowane jako różnica pomiędzy całkowitymi przychodami oraz kosztami (tzw. podatek Browna ${ }^{15}$ ) bądź podatki od nadwyżki zysków ${ }^{16}$.

Przyjmując za kryterium zakres opodatkowania, można z kolei wyróżnić m.in. daniny o charakterze ogólnym (nakładane na ogół podmiotów prowadzących działalność gospodarczą w danym kraju) oraz daniny o charakterze geologiczno-górniczym (obciążające wyłącznie podmioty prowadzące ściśle określoną działalność w analizowanym sektorze gospodarki). Na przykładzie Polski można wskazać podatek dochodowy od osób prawnych jako daninę o charakterze ogólnym oraz podatek od wydobycia niektórych kopalin jako daninę stricte sektorową. Należy jednak nadmienić, że rozwiązania funkcjonujące $\mathrm{w}$ polskim systemie prawnym znajdują się poza zakresem niniejszego opracowania. Na marginesie warto odnotować, że w ramach omawianej klasyfikacji w piśmiennictwie wyróżnia się również daniny za korzystanie ze środowiska ${ }^{17}$ uiszczane $\mathrm{w}$ ramach rekompensaty za podejmowane $\mathrm{w}$ ramach projektów wydobywczych działania

14 A. Krajewska, Podatki wydobywcze..., s. 177-184.

15 Podatek ten nakładany jest na stały procent przepływów gotówkowych netto $\mathrm{z}$ każdego projektu wydobywczego w danym okresie, przy czym płatny jest w razie osiągnięcia zysku netto (M. van Doorn-Olejnicka, Podatkowy słownik encyklopedyczny, IBFD, Amsterdam 2014, s. 383). Należy podkreślić, że podatek Browna ma charakter teoretyczny, nie występuje obecnie w jakimkolwiek państwie i jest w piśmiennictwie uznawany za model idealnie neutralny wobec decyzji inwestycyjnych, w ramach którego ogół przepływów (ujemnych oraz dodatnich) w dowolnym roku opodatkowany jest jednolitą stawką, odliczeniu nie podlegają zaś żadne koszty finansowe (A. Świstak, Opodatkowanie wydobycia surowców..., s. 206).

16 Uzasadnienie projektu u.p.w.n.k., s. 7.

17 Por. M. Ptak, Z. Kasztelewicz, Podatki i daniny płacone przez górnictwo w Polsce, „Zeszyty Naukowe Instytutu Gospodarki Surowcami Mineralnymi i Energią” 2014, nr 88 , s. 200. 
mogące mieć negatywny wpływ na środowisko naturalne. Przedmiotem dalszej analizy będą jednak wyłącznie daniny geologiczno-górnicze (przybierające zarówno formę danin typu royalty, jak i sektorowych podatków surowcowych), a także daniny ogólne (tj. standardowy podatek dochodowy od osób prawnych).

\section{Australia}

W australijskim systemie fiskalnym stosowanym w branży wydobywczej, oprócz klasycznego podatku dochodowego od osób prawnych (którego stawka wynosi zasadniczo $30 \%{ }^{18}$ ), stosowane są zarówno daniny obciążające wielkość wydobycia, jak i osiągany z tego tytułu zysk. Pierwsza grupa danin obejmuje opłaty typu royalties, stanowiące tzw. tantiemy górnicze należne rządowi (Governmental Mining Royalties) ${ }^{19}$, a będące wynagrodzeniem za prawa eksploatacji górniczej. Są one nakładane głównie na przedsięwzięcia wydobywcze realizowane na lądzie (onshore). Ich stawki są ustalane na poziomie ustawodawstwa stanowego i wynoszą zwykle od 10\% do $12,5 \%$ wartości wydobycia netto lub brutto ${ }^{20}$. Ich wysokość jest zasadniczo ustalana poprzez odjęcie kosztów odliczalnych od kwoty wydobycia brutto. Warto jednak nadmienić, że każdy stan może w tym zakresie określić własne zasady ich kalkulacji ${ }^{21}$.

Druga danina - podatek od korzystania z zasobów naftowych (petroleum resource rent tax - PRRT) - stanowi podatek typu federalnego i jest nakładany głównie na projekty morskie (offshore) związane z wydobyciem ropy naftowej ${ }^{22}$. Podatek ten stanowi rodzaj elastycznego podatku dochodowego, co oznacza, że opodatkowaniu podlega dochód rozumiany jako przychody z działalności wydobywczej pomniejszone o tzw. koszty odliczalne. Należy podkreślić, że możliwość odliczenia kosztów ograniczona

18 T. Toryanik, Australia - Corporate Taxation sec. 1, Country Tax Guides IBFD, pkt 1.10.1 (dostęp na dzień 4.09.2020).

19 Senackie Biuro Analiz i Dokumentacji, Analiza obciążén fiskalnych związanych $z$ wydobyciem kopalin w wybranych krajach, Warszawa 2012, s. 2, https://www.senat.gov. $\mathrm{pl} / \mathrm{gfx} /$ senat/pl/senatopracowania/31/plik/calosc_1_.pdf (dostęp: 4.09.2020).

${ }^{20}$ Global oil and gas tax guide 2019, przewodnik opracowany przez EY, s. 30, https:// www.ey.com/en_gl/tax-guides/global-oil-and-gas-tax-guide-2019 (dostęp: 4.09.2020).

21 Ibidem, s. 37.

22 Od 1 lipca 2012 r. PRRT obejmuje także projekty lądowe (onshore) oraz inwestycje realizowane w ramach North West Shelf Venture. 
jest wyłącznie do wydatków związanych z konkretnym przedsięwzięciem wydobywczym, dany wydatek nie może zaś zasadniczo zostać uznany za odliczalny w odniesieniu do więcej niż jednego projektu. Do kosztów odliczalnych można zaliczyć m.in.:

a) wydatki na poszukiwanie złóż (np. wiercenia poszukiwawcze czy badania sejsmiczne);

b) ogólne wydatki związane z projektem (np. koszty produkcji czy wydatki rozwojowe);

c) wydatki związane z rozpoczęciem wydobycia;

d) tzw. wydatki finalizacyjne (związane $\mathrm{z}$ zaniechaniem eksploatacji danego złoża i zamknięciem danej inwestycji wydobywczej);

e) wydatki ponoszone obowiązkowo w związku z korzystaniem z zasobów (np. sygnalizowane wyżej opłaty royalty czy akcyza) ${ }^{23}$.

Z kolei wydatkami, w odniesieniu do których australijski ustawodawca wyłączył możliwość rozliczania ich jako koszty podatkowe, są np. koszty związane z pozyskaniem finansowania, dywidendy, koszty emisji akcji lub udziałów czy też należności z tytułu podatku od towarów i usług. Obowiązek podatkowy w ramach analizowanej daniny powstaje w momencie przekroczenia przez szacowane wpływy kwoty kosztów odliczalnych ${ }^{24}$. Stawka podatku wynosi $40 \%$ dochodu podlegającego opodatkowaniu ${ }^{25}$. Płatność dokonywana w związku z uiszczaniem PRRT podlega odliczeniu dla celów kalkulacji podatku dochodowego ${ }^{26}$.

Należy również dodać, że kilka lat temu w Australii planowano wprowadzenie podatku od nadzwyczajnych zysków związanych z eksploatacją zasobów (resource super profit tax - RSPT), który miał zastąpić daniny typu royalties, a także zwiększyć udział państwa w zyskach osiąganych $\mathrm{z}$ eksploatacji nieodnawialnych zasobów bogactw naturalnych ${ }^{27}$. „Większa elastyczność tego podatku miała zachęcać do utrzymywania produkcji w sytuacji spadku cen lub wzrostu kosztów, a także ze złóż mniej efektywnych. [...] Miało to zwiększyć atrakcyjność inwestowania, a więc w konsekwencji zasób kapitału i efektywność siły roboczej. Planowane były też preferencje podatkowe dla małych przedsiębiorstw, a także wydatki na rozwój infrastruktury [...]. Według danych z 2011 r., RSPT wprowadzony został

${ }^{23}$ Global oil and gas tax guide 2019, s. 36.

24 Ibidem, s. 35.

25 T. Toryanik, Australia..., pkt 2.3.1.

26 Ibidem.

27 J. Neneman, J. Kronenberg, Opodatkowanie eksploatacji..., s. 48. 
w odniesieniu do instalacji offshore, wydobycie onshore jest nadal opodatkowane za pomocą royalties, nakładanych na poziomie lokalnym, a nie federalnym, jak w przypadku RSPT"28.

4. NorWEgIA

Norwegia określana jest mianem „gazowego mocarstwa na skalę europejską"29. Przedsiębiorcy prowadzący projekty wydobywcze na obszarze Norwegii oraz Norweskiego Szelfu Kontynentalnego (Norwegian continental shelf) muszą się liczyć z koniecznością uiszczania podatku dochodowego od osób prawnych oraz podatku surowcowego (resource rent tax) ${ }^{30}$. Wpływy z wskazanych danin zasilają budżet państwowy, nie zaś lokalne budżety gminne ${ }^{31}$.

Zakres opodatkowania uzależniony jest od rodzaju przedsięwzięcia wydobywczego (offshore lub onshore):

a) $\mathrm{w}$ przypadku projektów wydobywczych offshore, tj. prowadzonych na platformach wiertniczych w ramach działalności morskiej, podlegają one opodatkowaniu zarówno podatkiem dochodowym od osób prawnych (22\%), jak i podatkowi surowcowemu (56\%). Oznacza to, że łączny poziom opodatkowania w odniesieniu do projektów offshore sięga aż 78\% osiągniętego dochodu;

b) w przypadku projektów wydobywczych onshore, tj. prowadzonych na lądzie, podlegają one wyłącznie opodatkowaniu podatkiem dochodowym od osób prawnych (22\%).

$\mathrm{Na}$ powyższym tle uwidacznia się znaczna różnica w obciążeniach podatkowych pomiędzy przedsięwzięciami wydobywczymi prowadzonymi na lądzie oraz na morzu. Stawkę w wysokości 78\% stosowaną w odniesieniu do projektów offshore należy uznać za wysoką i istotnie obciążającą dochody osiągane z tytułu realizacji projektów morskich. Z drugiej strony realizacja projektów offshore prowadzonych na morskich platformach

28 Ibidem.

${ }^{29}$ K. Skołucka, M. Sobiczewski, Modele opodatkowania węglowodorów na świecie. Założenia ustawy o specjalnym podatku weglowodorowym oraz innych zmian prawno-podatkowych dotyczących eksploatacji węglowodorów w Polsce, „Kultura i Polityka” 2012, nr 12, s. 36.

${ }^{30}$ Global oil and gas tax guide 2019, s. 488.

31 E. Furuseth, Norway - Corporate Taxation sec. 2, Country Tax Guide IBFD, pkt 2.3.1 (dostęp: 4.09.2020). 
wiertniczych może się wiązać z uzyskiwaniem znacznie większych zysków niż w przypadku prac lądowych, co może uzasadniać nałożenie na nie dodatkowego, stosunkowo wysokiego podatku.

Podstawą opodatkowania $\mathrm{w}$ norweskim podatku surowcowym jest dochód uwzględniany przy obliczaniu podatku dochodowego od osób prawnych. W odniesieniu do podlegającego opodatkowaniu dochodu osiąganego w związku z wydobyciem ropy naftowej i gazu oraz związanym z nim transportem wodociągowym, można ponadto wskazać szczególne zasady związane z jego ustalaniem. Wartość dochodu brutto oraz zapasów ropy naftowej podlega wycenie według cen standardowych (norm prices) ${ }^{32}$. Istnieje możliwość dokonania odliczenia z tytułu amortyzacji do maksymalnie 16 i $2 / 3 \%$ w skali roku według metody liniowej ${ }^{33}$. Straty operacyjne $z$ analizowanej działalności mogą być przenoszone na czas nieokreślony. Przed wyliczeniem podatku surowcowego podstawa opodatkowania może być dodatkowo pomniejszona o kwotę równą 5,2\% kosztów aktywów podlegających amortyzacji (tzw. uplift) ${ }^{34}$.

Dochód osiągnięty z projektów offshore nie może być zasadniczo zaliczany na poczet straty z działalności onshore i odwrotnie ${ }^{35}$. Ponadto kwota podatku surowcowego nie podlega odliczeniu dla celów kalkulacji podatku dochodowego od osób prawnych ${ }^{36}$.

5. KANADA

Na podmiotach prowadzących działalność wydobywczą w Kanadzie spoczywa obowiązek uiszczania zarówno standardowego podatku dochodowego od osób prawnych, jak i opłaty typu royalty, której wysokość uzależniona jest od wielkości wydobycia. W tym miejscu należy odnotować, że w Kanadzie dochód osiągany przez osoby prawne opodatkowany jest na dwóch poziomach:
a) federalnym (krajowym) oraz
b) regionalnym (na poziomie prowincji $)^{37}$.

32 Są to ceny surowców naftowych ustalane administracyjnie przez specjalnie wyznaczony organ (Norm Price Board) w celu kalkulacji podlegającego opodatkowaniu dochodu ze sprzedaży produktów naftowych, niezależnie od ich ceny rzeczywistej.

33 E. Furuseth, Norway..., pkt 2.3.1.1.

${ }^{34}$ Ibidem.

${ }^{35}$ Global oil and gas tax guide 2019, s. 489.

${ }^{36}$ E. Furuseth, Norway..., pkt 2.3.1.

37 Por. K. Skołucka, M. Sobiczewski, Modele opodatkowania węglowodorów na świecie..., s. 33. 
Stawka podatku dochodowego od osób prawnych wynosi obecnie zasadniczo $15 \%$ na szczeblu federalnym ${ }^{38}$ oraz od $8 \%$ do $16 \%$ na szczeblu regionalnym, w zależności od zasad przyjętych w poszczególnych prowincjach ${ }^{39}$.

Producenci ropy naftowej oraz gazu są również zobowiązani do uiszczania na rzecz posiadacza praw do bogactw naturalnych opłaty typu royalty, która jest w Kanadzie określana mianem „należności korony” (Crown royalties). Należy dodać, że większość praw do kanadyjskich bogactw naturalnych przysługuje rządom (na szczeblu prowincjonalnym, terytorialnym oraz federalnym) lub grupie tzw. Pierwotnych Narodów ${ }^{40}$

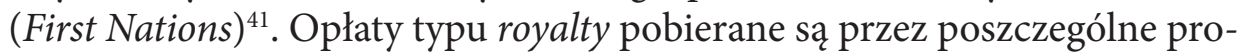
wincje w ustalonej przez nie wysokości. Danina ta jest także nakładana przez rząd federalny na działalność wydobywczą prowadzoną na terenach znajdujących się pod kontrolą federalną ${ }^{42}$. Kanadyjskie royalties to daniny o złożonym charakterze, których kształt uzależniony jest w głównej mierze od prowincji, na obszarze której wydobywane są podlegające im kopaliny. Opłaty te są równe określonemu procentowi produkcji ${ }^{33}$, zasadniczo nie przekraczają $45 \%{ }^{44}$. Ich kwota od 2007 r. podlega odliczeniu przy ustalaniu dochodu dla celów podatkowych (do końca 2006 r. odliczenie to nie było możliwe, zaś podatnicy mieli możliwość skorzystania w tym zakresie ze specjalnej ulgi - resource allowance $)^{45}$.

$\mathrm{Na}$ marginesie warto odnotować, że kanadyjski system podatkowy przewiduje możliwość zastosowania rozmaitych zachęt i zwolnień

38 B.P. Dwyer, Canada - Corporate Taxation sec. 1, Country Tax Guides IBFD, pkt 1.10.1.1 (dostęp na dzień 4 września 2020 r.).

39 Ibidem, pkt 1.10.1.2.1.

40 Są to Indianie kanadyjscy będący jedną z trzech rdzennych grup ludności zamieszkujących Kanadę. Warto w tym kontekście dodać, że od 1987 r. funkcjonuje w Kanadzie agencja regulacyjna odpowiedzialna za zarządzanie poszukiwaniem i gospodarowaniem złożami węglowodorów na terenach należących do Pierwszych Narodów (Indian Oil and Gas Canada - IOGC). Przedsiębiorcy chcący prowadzić na tych obszarach działalność wydobywczą muszą uzyskać stosowne licencje i pozwolenia właśnie od wskazanego podmiotu, por. Global oil and gas tax guide 2019, s. 103; Annual Report: 2014-2015 Indian Oil and Gas Canada (IOGC), https://www.pgic-iogc.gc.ca/eng/1452544281030/15096475364 09\#chp3 (dostęp: 6.09.2020).

41 Global oil and gas tax guide 2019, s. 103.

42 B.P. Dwyer, Canada..., pkt 12.5.6.

${ }^{43}$ Ibidem.

${ }^{44}$ Global oil and gas tax guide 2019, s. 103-104.

45 B.P. Dwyer, Canada..., pkt 12.5.6. 
w odniesieniu do działalności wydobywczej, np. skorzystania z kredytu podatkowego na cele inwestycyjne, przyspieszonej amortyzacji określonych aktywów czy też „wakacji podatkowych”46.

\section{MeKsyk}

Obowiązujący w Meksyku system związany z wydobyciem bogactw naturalnych stanowi kombinację systemu koncesyjnego oraz kontraktowego. W odniesieniu do węglowodorów system ten przybrał aktualny kształt na skutek reformy energetycznej obowiązującej od lat 2014-2015 ${ }^{47}$. Przed wskazaną reformą prawa w zakresie poszukiwania, wydobywania, pierwszej sprzedaży i dystrybucji podstawowych produktów petrochemicznych przysługiwały wyłącznie jednemu podmiotowi będącemu zdecentralizowaną agencją rządową (Petróleos Mexicanos - Pemex). Na skutek powyższej reformy Pemex stał się państwową spółką produkcyjną, która w celu prowadzenia działalności w zakresie poszukiwania i wydobywania węglowodorów, podobnie jak inne tego rodzaju przedsiębiorstwa, może:

a) uzyskać od państwa stosowną koncesję lub

b) zawrzeć z państwem jeden z poniższych kontraktów ${ }^{48}$ :

- kontrakt licencyjny (licence contract), w ramach którego dochodzi do transferu wydobytych węglowodorów na wykonawców, którzy dokonują z tego tytułu określonych płatności na rzecz państwa;

- kontrakt na wspólną produkcję oraz o podziale zysków ${ }^{49}$ (production and profit sharing contract), w ramach którego rządowi przekazywana jest dodatkowo określona kwota zysku operacyjnego;

46 Senackie Biuro Analiz i Dokumentacji, Analiza obciążeń fiskalnych..., s. 3.

47 E. Orellana Polo, Mexico - Corporate Taxation sec. 2, Country Tax Guides IBFD, pkt 2.3.2. (dostęp: 5.09.2020).

${ }^{48}$ Ibidem.

${ }^{49}$ Różnica pomiędzy kontraktami na wspólną produkcję oraz o podziale zysku polega na tym, że w przypadku pierwszej wskazanej kategorii Meksykański Fundusz Naftowy otrzymuje całą produkcję węglowodorów oraz dokonuje stosownego jej podziału pomiędzy państwo oraz przedsiębiorcę. $Z$ kolei $w$ ramach drugiej grupy umów w procesie przepływu produkcji oraz związanych z nią dochodów występuje dodatkowe ogniwo - cała produkcja węglowodorów dostarczana jest bowiem państwowemu dystrybutorowi, który wpływy z jej sprzedaży przekazuje Meksykańskiemu Funduszowi Naftowemu, ten zaś w dalszej kolejności rozdziela otrzymaną płatność pomiędzy państwo oraz przedsiębiorcę prowadzącego działalność wydobywczą (por. Global oil and gas tax guide 2019, s. 413-414). 
- kontrakt usługowy (service contract), w ramach którego wykonawcy są zobowiązani do świadczenia na rzecz państwa określonych usług związanych $\mathrm{z}$ działalnością wydobywczą węglowodorów w zamian za zapłatę w gotówce ${ }^{50}$.

W zależności od relacji z państwem w kontekście działalności wydobywczej (koncesyjnej lub kontraktowej) przedsiębiorcy zobowiązani są do uiszczania licznych należności. Dalsze rozważania koncentrują się na daninach nałożonych w ramach stosunków kontraktowych na wykonawców, tj. podmioty będące zarówno państwowymi przedsiębiorstwami produkcyjnymi, jak i meksykańskimi firmami prywatnymi, trudniące się poszukiwaniem i wydobyciem węglowodorów. W zależności od rodzaju zawartego kontraktu podmioty te mają obowiązek ponoszenia m.in. następujących obciążeń fiskalnych:

a) standardowego podatku dochodowego od osób prawnych (30\%). Należy w tym miejscu dodać, że przedsiębiorcy prowadzący działalność wydobywczą dla celów obliczenia podatku dochodowego mogą odliczyć $100 \%$ pierwotnej kwoty inwestycji na poszukiwania złóż, 25\% pierwotnej kwoty inwestycji na rozwój i wydobycie oraz 10\% pierwotnej kwoty inwestycji na infrastrukturę magazynową i transportową ${ }^{51}$;

b) podatku od poszukiwania i wydobycia węglowodorów (tax on hydrocarbons exploration and extraction activities - THEXA) - jego celem jest naprawa szkód ekologicznych wyrządzonych w wyniku działań podejmowanych w ramach poszukiwania złóż węglowodorów oraz ich eksploatacji. Danina ta jest uiszczana miesięcznie, jej wysokość jest zaś uzależniona od fazy przedsięwzięcia wydobywczego oraz obszaru, na którym prowadzone są prace wydobywcze:

- w fazie eksploracji (poszukiwania węglowodorów) - THEXA wynosi 1820,97 pesos meksykańskich $(\mathrm{MXN}) / \mathrm{km} \mathrm{kw}$;

- w fazie produkcji (wydobycia węglowodorów) - THEXA wynosi 7283,92 MXN/km kw..$^{52}$;

c) opłat typu royalties, których wysokość uzależniona jest od rodzaju wydobywanej kopaliny oraz jej ustalonej ceny umownej, a także płatności opartych na wartości węglowodorów (over-royalties) - druga ze wskazanych kategorii obejmuje dodatkowe płatności na rzecz państwa,

${ }^{50}$ Ibidem, s. 411-414.

51 E. Orellana Polo, Mexico - Corporate..., pkt 2.3.2.3.

${ }^{52}$ Ibidem, pkt 2.3.2.4. 
których podstawę stanowi określony wskaźnik procentowy związany z wartością wydobytych węglowodorów ${ }^{53}$;

d) opłat umownych za określony okres poszukiwawczy - są to okresowe płatności dokonywane przed rozpoczęciem prac wydobywczych, podlegające corocznej waloryzacji w oparciu o wskaźnik bazujący na krajowym indeksie cen towarów i usług konsumenckich; w 2019 r. wskazana opłata wynosiła:

- 1355,82 MXN - przez pierwsze 60 miesięcy;

- 3242,17 MXN - po upływie 60 miesięcy ${ }^{54}$;

e) premii z tytułu podpisania kontraktu - jest to dodatkowa, ryczałtowa płatność, uiszczana na rzecz państwa z góry przy zawieraniu kontraktu licencyjnego; szczegóły dotyczące jej wysokości oraz warunków wypłaty są określane przez meksykańskie Ministerstwo Finansów w odniesieniu do poszczególnych kontraktów i precyzowane podczas procedury przetargowej ${ }^{55}$;

f) płatności związanej z przekazaniem rządowego procentu zysku operacyjnego - w przypadku kontraktów na wspólną produkcję oraz o podziale zysków ${ }^{56}$.

\section{Podsumowanie}

Poszczególne państwa wykształciły różnorodne systemy związane z opodatkowaniem wydobycia bogactw naturalnych, w ramach których stosowane są rozmaite narzędzia fiskalne. Przyjęcie odpowiednich rozwiązań w tym zakresie oparte jest na wielu czynnikach, do których należy zaliczyć uwarunkowania gospodarcze, geologiczne, historyczne i polityczne. Czynniki te nie mają charakteru stałego, dlatego też stopniowym zmianom podlegają również przyjęte w analizowanym sektorze gospodarki mechanizmy opodatkowania. Zastosowanie unikatowej kombinacji instrumentów fiskalnych umożliwia poszczególnym krajom wypracowanie systemu dopasowanego do ich specyfiki, potencjału wydobywczego, aktualnej sytuacji ekonomicznej i założeń długofalowej polityki surowcowej.

\footnotetext{
${ }^{53}$ Global oil and gas tax guide 2019, s. 412.

${ }^{54}$ Ibidem.

55 Ibidem, s. 411.

56 Ibidem, s. 413.
} 
W światowym górnictwie funkcjonują systemy koncesyjne oraz kontraktowe. Pierwsze $\mathrm{z}$ nich przewidują udzielenie przez państwo stosownej koncesji na rzecz podmiotów prowadzących działalność wydobywczą, umożliwiającej eksploatację złóż bogactw naturalnych. Drugie zaś oparte są na kontraktach zawieranych przez państwo z przedsiębiorcami, które mogą przybierać różne formy i zakładać odmienne zasady współpracy i rozliczeń. W ramach obu wskazanych systemów podmioty dokonujące wydobycia zobowiązane są do uiszczania określonych danin na rzecz państwa występującego w tej relacji jako gospodarz złóż podlegających eksploatacji. Daniny te mają rozmaity charakter, podlegają licznym klasyfikacjom, a ich wysokość może być uzależniona od wielu czynników (m.in. od wielkości wydobytej kopaliny bądź zysku osiągniętego w związku z jej wydobyciem).

W krajach poddanych analizie w ramach niniejszego artykułu oprócz powszechnego opodatkowania podatkiem dochodowym od osób prawnych (właściwego dla ogółu podmiotów prowadzących działalność gospodarczą, niezależnie od branży) przedsiębiorcy trudniący się wydobyciem kopalin są zobowiązani do uiszczania zarówno opłat typu royalties, opartych zasadniczo na wielkości wydobycia (w przypadku Australii, Kanady i Meksyku), jak i podatków surowcowych, nakładanych na płynące z wydobycia zyski i stanowiące $\mathrm{w}$ istocie elastyczne odmiany podatku dochodowego (w przypadku Australii i Norwegii). Najwyższy spośród badanych państw poziom obciążeń fiskalnych w sektorze wydobywczym można zaobserwować w Norwegii, gdzie w odniesieniu do przedsięwzięć wydobywczych offshore zastosowanie znajduje relatywnie wysoka stawka podatkowa sięgająca łącznie aż 78\% dochodów osiąganych z działalności wydobywczej (wynikająca $z$ opodatkowania podatkiem dochodowym od osób prawnych oraz sektorowym podatkiem surowcowym).

\section{BIBLIOGRAFIA}

Annual Report: 2014-2015 Indian Oil and Gas Canada (IOGC), https://www.pgic-iogc. gc.ca/eng/1452544281030/1509647536409\#chp3 (dostęp: 6.09.2020).

Doorn-Olejnicka van M., Podatkowy słownik encyklopedyczny, IBFD, Amsterdam 2014.

Dwyer B.P., Canada - Corporate Taxation sec. 1, Country Tax Guides IBFD.

Furuseth E., Norway - Corporate Taxation sec. 2, Country Tax Guide IBFD.

Global oil and gas tax guide 2019, przewodnik opracowany przez EY, https://www.ey.com/ en_gl/tax-guides/global-oil-and-gas-tax-guide-2019 (dostęp: 4.09.2020).

Grabicz M., Sokół H., Pułapki opodatkowania gazu łupkowego w Polsce, „Rynek Energii” 2012, nr 3. 
Krajewska A., Podatki wydobywcze - ocena systemu opodatkowania wydobycia niektórych kopalin w Polsce na tle rozwiązań wybranych krajów, rozprawa doktorska obroniona na Wydziale Prawa i Administracji Uniwersytetu Łódzkiego w 2019 r.

Kulczycka J., Nieć M., Uberman R., Określenie ilości wydobytej kopaliny stałej przy naliczaniu opłaty eksploatacyjnej. Pojęcia i zasady, Kraków 2003.

Land B.C., Resource rent taxes: A re-appraisal, [w:] The Taxation of Petroleum and Minerals: Principles, Problems and Practice, red. P. Daniel, M. Keen, C. McPherson, International Monetary Fund 2010.

Neneman J., Kronenberg J., Opodatkowanie eksploatacji złóż gazu łupkowego w Polsce i jego wpływ na gospodarkę w świetle koncepcji "przekleństwa zasobów naturalnych”, „Acta Universitatis Lodziensis. Folia Oeconomica” 2014, nr 5.

Orellana Polo E., Mexico - Corporate Taxation sec. 2, Country Tax Guides IBFD.

Projekt z dnia 19 stycznia 2012 r. ustawy o podatku od wydobycia niektórych kopalin wraz z uzasadnieniem, druk sejmowy nr 144/VII kadencja (dostęp: 3.09.2020).

Ptak M., Kasztelewicz Z., Podatki i daniny płacone przez górnictwo w Polsce, „Zeszyty Naukowe Instytutu Gospodarki Surowcami Mineralnymi i Energią” 2014, nr 88.

Senackie Biuro Analiz i Dokumentacji, Analiza obciążeń fiskalnych związanych z wydobyciem kopalin w wybranych krajach, Warszawa 2012, https://www.senat.gov.pl/gfx/ senat/pl/senatopracowania/31/plik/calosc_1_.pdf (dostęp: 4.09.2020).

Skołucka K., Sobiczewski M., Modele opodatkowania węglowodorów na świecie. Założenia ustawy o specjalnym podatku weglowodorowym oraz innych zmian prawno-podatkowych dotyczących eksploatacji węglowodorów w Polsce, „Kultura i Polityka” 2012, nr 12.

Świstak A., Opodatkowanie wydobycia surowców naturalnych w Polsce, Warszawa 2018. Tordo S., Fiscal Systems for Hydrocarbons, World Bank Working Paper No. 123, Washington 2007.

Toryanik T., Australia - Corporate Taxation sec. 1, Country Tax Guides IBFD.

\section{SEVERAL REMARKS ON TAXATION OF MINERALS' EXTRACTION IN SELECTED COUNTRIES}

Summary. The article gives a brief overview of extractive taxes within the fiscal systems of selected countries. Firstly, the notion of "resource rent" is explained as well as systems of the cooperation between the state owning the mineral resources and entrepreneurs extracting them are presented (i.e. concessionary and contractual system). Next, a brief description of the most common levies imposed on the extractive activities is made, along with their classification according to various criteria. Then, fiscal instruments applied in the extractive sector in Australia, Norway, Canada and Mexico are presented (mainly regarding hydrocarbons, i.e. crude oil and natural gas).

Keywords: taxation of minerals' extraction, taxation of the extractive industry, extractive taxes, resource rent 